\title{
Adhesion of Streptococcus mutans on glazed IPS e.max press, glazed feldspatic and dental enamel
}

\author{
Ezzatollah Jalalian', Fahimeh Sarzaeem ${ }^{2 *}$ and Mahkameh Koochaki Pourchafjiri ${ }^{3}$ \\ ${ }^{1}$ Associate Professor, Department of Fixed Prosthodontics, Member of Dental Material Research Center, \\ Dental Branch, Islamic Azad University, Tehran, Iran \\ ${ }^{2}$ Postgraduate Student, Department of Fixed Prosthodontics, Islamic Azad University, Tehran, Iran \\ ${ }^{3}$ Dentist
}

\section{ABSTRACT}

Despite several researches done to determine accuracy of microbial growth in the restoration treatment, the mechanisms for these reports is still unclear.The aim of the study was to comparison adhesion of the Streptococcus mutans on glazed IPS e.max press, glazed feldspatic and dental enamel. The in vitro study was done on 15 samples: 5 glazed IPS e.max, 5 glazed feldspatic and 5 dental enamels for vicinity of the bacterial suspension containing Streptococcus mutans $\left(10 \times 10^{6} \mathrm{cell} / \mathrm{mLit}\right)$. After 48 hours, Streptococcus mutans colonies were counted with the naked eye. The mean Streptococcus mutans attached to dental enamel was $24.4 \pm 8.44(\mathrm{P}<0.001)$. The Streptococcus mutans attached to glazed IPS e.max was $1.8 \pm 0.83$. The Streptococcus mutans attached to glazed feldspatic was $1.4 \pm 0.54$. No significant differences observed between the IPS e.max and feldspatic $(\mathrm{P}<0.8)$. The results showed Streptococcus mutans adhesion to enamel was higher than glazed IPS e.max and glazed feldspatic ceramic material.

KEY WORDS: IPS E.MAX, FELDSPATIC, STREPTOCOCCUS MUTANS

\section{INTRODUCTION}

There is a rich ecosystem in the oral cavity, with a countless number of microorganisms. Although both periodontal disease and dental caries are considered multifactorial diseases, the bacteria in the dental plaque are the main factor in their onset and progression. Increased oral microbiota of Streptococcus mutans and Lactobacillus is associated with the onset of tooth demineralization and periodontal disease. This condition is much more frequent in orthodontic patients with greater risk of colonization by these microorganisms ( Brusca et al. 2007, Harikrishnan et al. 2013, Nascimento et al. 2014 Jalalian et al. 2015Duymus et al. 2016).

\section{ARTICLE INFORMATION:}

*Corresponding Author: sarzaeem@yahoo.com

Received $12^{\text {th }}$ June, 2017

Accepted after revision $21^{\text {st }}$ Sep, 2017

BBRC Print ISSN: 0974-6455

Online ISSN: 2321-4007 CODEN: USA BBRCBA

Thomson Reuters ISI ESC and Crossref Indexed Journal

NAAS Journal Score 2017: 4.31 Cosmos IF: 4.006

- A Society of Science and Nature Publication, 2017. All rights reserved.

Online Contents Available at: http//www.bbrc.in/

DOI: $10.21786 / \mathrm{bbrc} / 10.3 / 28$ 
Despite several researches done to determine accuracy of microbial growth in the restoration treatment, the mechanisms for these reports is still unclear However the saliva composition and secretion rate also influence plaque formation (Gameiro et al. 2009).Porcelain has excellent esthetic properties and biocompatibility, and major emphasis in research have been directed toward the enhancement of its strength and aesthetic properties (Rashid, 2014).

Scarce reports exist on bacterial adhesion to porcelain restorations (Kamala and Annapurni, 2006). A previous research stated the best results were obtained through glazing, since it provided a surface topography with minimal bacterial affinity (Sarac et al. 2006). Additionally, it is demonstrated that polished surfaces had lower bacterial adhesion than glazed surfaces (Kawai et al. 2000). In a similar study, Jalalian et al. (2015) reported the adhesion of Streptococcus mutans to the enamel was higher than that to polished IPS e.max Press and polished feldspathic porcelain. However, there is no report comparing effect of porcelains with natural dental enamel. So, the aim of the current study was to determine adhesion of the Streptococcus mutans on glazed IPS e.max press, glazed feldspatic and dental enamel adhesion using in vitro condition.

\section{MATERIAL AND METHODS}

The in vitro study was done on 15 samples: 5 glazed IPS e.max, 5 glazed feldspatic and 5 dental enamels for vicinity of the bacterial suspension containing Streptococcus mutans ( $\left.10^{9} \mathrm{cell} / \mathrm{mLit}\right)$. The samples had diameter $5 \times 2 \mathrm{~mm}$ in laboratory, then phosphate base fabricated. The feldspatic samples fabricated using feldspatic powders (lvocular, Germany) based on manufacture instructions. Ito fabricate IPS e.max press samples, $2 \times 5 \mathrm{~mm}$ were blocks produced. The dental enamels obtained from normal premolar using diamond disks. The samples glazed at $625^{\circ} \mathrm{C}$ beginning temperature and increased each 20 minutes until final $920^{\circ} \mathrm{C}$, then cooled in fresh air. Samples washed using distilled water then autoclave.

\section{STUDY PROTOCOL}

To increase hygiene condition, all samples were located into ultrasonic system for $15 \mathrm{~min}$ and then transferred into $70 \%$ alcohol for $30 \mathrm{~min}$. the being sterile of the samples was tested using BHI condition for $24 \mathrm{~h}$. Saliva samples obtained from 2 healthy patients which had no medication for last 3 months without dental caries or periodontal disease. The saliva samples sterile using autoclave (Garcez et al. 2011). Then samples coated with saliva, put into glass vials and immersed in $2 \mathrm{~mL}$ of Streptococcus mutans (PTCCI 683) suspension $\left(\times 10^{9}\right.$
CFU) and incubated in $37{ }^{\circ} \mathrm{C}$ and $5 \% \mathrm{CO}_{2}$ for $24 \mathrm{~h}$. Samples washed 3 times with normal saline, immersed into $2 \mathrm{~mL}$ of normal saline and shacked for $2 \mathrm{~min}$ (Fournier et al. 1998). Obtained suspension cultured on blood agar and incubated in $37{ }^{\circ} \mathrm{C}$ with $5 \% \mathrm{CO}_{2}$ for $48 \mathrm{~h}$ and the colonies counted (Kantoriski et al. 2006). After 48 hours, Streptococcus mutans colonies were counted with the naked eye.

\section{STATISTICAL ANALYSIS}

Data for bacteria load was analyzed by one way analysis of variance (ANOVA) using SPSS 16.0 for Windows and is presented as mean $\pm \mathrm{Sd}$. For treatments showing a main effect by ANOVA, means were compared using Tukey HSD test. $\mathrm{P}<0.05$ was considered as significant differences between treatments.

\section{RESULTS AND DISCUSSION}

As seen in table, the mean Streptococcus mutans attached to dental enamel was $24.4 \pm 8.44(\mathrm{P}<0.001)$. The Streptococcus mutans attached to glazed IPS e.max was $1.8 \pm 0.83$. The Streptococcus mutans attached to glazed feldspatic was $1.4 \pm 0.54$. No significant differences observed between the IPS e.max and feldspatic $(\mathrm{P}<0.8)$.

\begin{tabular}{|l|l|l|}
\multicolumn{3}{|l|}{ Table 1. The adhesion of streptococcus } \\
mutans on different restoration \\
\hline & adhesion & C.V \\
\hline Feldspatic & $1.4 \pm 0.54$ & 38.57 \\
\hline IPS e.max & $1.8 \pm 0.83$ & 46.11 \\
\hline Dental enamel & $24.4 \pm 8.44$ & 34.59 \\
\hline P value & 0.001 & \\
\hline
\end{tabular}

As observed in the current study, Streptococcus mutans attached was lower in glazed feldspatic $<$ IPS

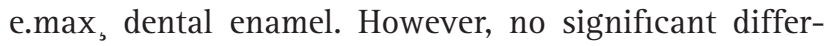
ence observed between glazed feldspatic and IPS e.max. Bacteria-dental interactions typical of enamel or cementum surfaces, in vivo biofilm formation on restorative surfaces have physiochemical and biochemical interactions (Hara and Zero, 2010). Pathogenic communities involving Bifidobacterium dentium, Scardovia wiggsiae, Bifidobacterium longum, Bifidobacterium adolecentis, Prevotella spp, Selenomonas spp and Lactobacilli spp have also been demonstrated to be complicit in the etiology of dental caries (Zhang et al. 2015). Streptococcus mutans has been demonstrated as the primary etiologic agent in caries initiation and reductionist approach can elucidate vital information regarding its interaction with restoration surfaces; however, additional studies may also use a more holistic approach (Wessel et al. 2014). 
The first stage of colonization by an organism involves adherence of the organism to a host surface. From this viewpoint, evaluation of Streptococcus mutans adhesion and colonization to tooth surfaces and restorative materials are of most importance for their success (Lassila et al. 2009). Eick et al. (2004) demonstrated that no correlation found between surface roughness and the number of Streptococcus mutans. In the oral environment, the adsorption of salivary proteins to the tooth or restorative surface precedes and promotes bacterial adherence. They can form an acquired salivary pellicle to which bacteria and structural substrates may bind (Keulemans et al. 2009). Plaque accumulation was more influenced by the presence of a salivary pellicle than by material type. Viability, however, was influenced by material composition, in this case, differentiated by glass content (Dittmer et al. 2015).

Feldspathic porcelains are usually used as a veneering material for metal ceramic restorations and provide excellent esthetics and compressive strength (Duymus et al. 2016). Otherwise, the rough porcelain surface is prone to adhesion and retention of oral microorganisms causing excessive plaque accumulation, gingival irritation, increased surface staining and poor esthetics of the restored teeth and thereby increasing the risk of dental caries and periodontal disease (Hengtrakool et al. 2011).

The oral cavity is a complex, aqueous environment where the restorative material is in contact with saliva (Hengtrakool et al. 2011). Other factors such as low pH due to acidic foods and drinks may influence the material's mechanical and physical characteristics (Honorio et al. 2008). The availability and long-term success of prosthesis, depends upon the protection of the polished surface. The degradation of surface finish will cause the formation of surface cracks and after a while, leaving the porcelain metal sub-structure. In addition, surface deterioration will facilitate the involvement of plaque and microorganisms (Honorio et al. 2008).

Karayazgan et al. (2010) reported that the level of adhesion of Candida albicans to the polished surface of feldspathic porcelain was $3.4 \pm 0.25$ colonies $/ \mathrm{mm}^{2}$. In a similar study, enamel used as the control for assessment of the adhesion of Streptococcus mutans to uncoated and saliva-coated glass ceramics and composites (Kantorski et al. 2008) and their report was consistent with the findings of the current study. In a research on the adhesion to different the ceramics, composites and amalgam concluded the bacterial affinity was equal in all groups of ceramics assessed (Kawai et al. 2000). In conclusion the results showed Streptococcus mutans adhesion to enamel was higher than glazed IPS e.max and glazed feldspatic ceramic material. According to the findings of the present study, polished IPS e.max Press and polished feldspathic porcelain exhibit similar char- acteristics in terms of bacterial adhesion and either one can be the choice material.

\section{REFERENCES}

Brusca MI, Chara 0, Sterin-Borda L, Rosa AC.2007 Influence of different orthodontic brackets on Adherence of microorganisms in vitro. Angle Orthod. 77(2):331-6.

Dittmer MP, Hellemann CF, Grade S, Heuer W, Stiesch M, Schwestka-Polly R, Demling AP 2015 Comparative threedimensional analysis of initial biofilm formation on three orthodontic bracket materials. Head \& Face Medicine 11:10 DOI 10.1186/s13005-015-0062-0

Eick S, Glockmann E, Brandl B, Pfister W. 2004 Adherence of Streptococcus mutans to various restorative materials in a continuous flow system. J Oral Rehabil 2004; 31: 278-85.

Fournier A, Payant L, Bouclin R. 1998 Adherence of Streptococcus mutans to orthodontic brackets. Am J Orthod Dentofacial Orthop 114(4):414-7.

Gameiro GH, Nouer DF, Cenci MS, Cury JA. 2009 Enamel demineralization with two forms of archwire ligation investigated using an in situ caries model: a pilot study. Eur J Orthod. 31(5):542-6.

Garcez AS, Suzuki SS, Ribeiro MS, Mada EY, Freitas AZ, Suzuki H. 2011 Biofilm retention by 3 methods of ligation on orthodontic brackets: A microbiologic and optical cohernce tomography analysis. American Journal of Orthodontics and Dentofacial Orthopedics 140 (4), 193-198.

Hara AT, Zero DT. 2010 The caries environment: saliva, pellicle, diet, and hard tissue ultrastructure. Dent Clin North Am 54:455-67.

Harikrishnan P, SakuSubha T, Kavitha V, Gnanamani A. 2013 Microbial Adhesion on Orthodontic Ligating Materials: An in Vitro Assessment. Advances in Microbiology, 3: p- 108-114.

Hengtrakool C, Kukiattrakoon B, Kedjarune-Leggat U. (2011) Effect of Naturally Acidic Agents on Microhardness and Surface Micromorphology of Restorative Materials. European Journal of Dentistry, 5, 89-100.

Honorio, H.M., Rios, D., Francisconi, L.F., et al. (2008) Effect of Prolonged Erosive pH Cycling on Different Restorative Materials. Journal of Oral Rehabilitation, 35, 947-953.

Jalalian E, Mofrad GH, Rahbar M, Mohseni A, Mohebbi M. 2015 In vitro adhesion of streptococcus mutans to polished IPS e.max and Feldspathic porcelain. Journal of Islamic Dental Association of IRAN (JIDAI) 27(4):182-185.

Jalalian E, Mostofi SN, Shafiee E, Nourizadeh A, Nargesi RA, Ayremlou S. 2015 Adhesion of Streptococcus mutans to Zirconia, Titanium Alloy and some other Restorative Materials:" An in-vitro Study". Advances in Biosciences \&t Clinical Medicine. Jan 1;3(2):13-20.

Kamala KR, Annapurni H. 2006 Evaluation of surface roughness of glazed and polished ceramic surface on exposure to fluoride gel, bleaching agent and aerated drink: An in vitro study. J of Indian Prosthod Soc. Jul; 6(3):128-32. 
Kantoriski KZ, Scotti R, Felipe L. 2006 Surface roughness and Bacterial Adherence.Cience Odontol bras. 9(4):12-17.

Kantorski KZ, Scotti R, Valandro LF, Bottino MA, Koga-Ito CY, Jorge A0. 2008 Adherence of Streptococcus mutans to uncoated and salivacoated glass-ceramicsand composites. Gen Dent. Nov-Dec;56(7):740-7.

Karayazgan B, Atay A, Saracli MA, Gunay Y. 2010 Evaluation of Candida albicans formation on feldspathic porcelain subjected to four surface treatment methods. Dent Mater J. Mar; 29(2): 147-53.

Kawai K, Urano M, Ebisu S.2000 Effect of surface roughness of porcelain on adhesion of bacteria and their synthesizing glucans. J Prosthet Dent. Jun;83(6):664-7.

Keulemans F, Lassila LV, Garoushi S, Vallittu PK, Kleverlaan CJ, Feilzer AJ. 2009 The influence of framework design on the loadbearing capacity of laboratory-made inlay-retained fiber reinforced composite fixed dental prostheses. J Biomech 42: 844-9.

Lassila LVJ, Garoushi S, Tanner J, Vallittu PK, Söderling E. 2009 Adherence of Streptococcus mutans to fiber-reinforced filling composite and conventional restorative materials. The Open Dentistry Journal, 3, 227-232.

Nascimento LEAG, Souza MMG, Azevedo ARP, Maia LC.2014 Are self-ligating brackets related to less formation of Streptococcus mutans colonies? A systematic review. Dental Press J Orthod. 19(1):60-8.

Rashid H. 2014 The effect of surface roughness on ceramics used in dentistry: A review of literature. Eur J Dent 8:571-9.

Sarac D, Sarac YS, Kulunk S, Ural C, Kulunk T.2006 The effect of polishingtechniques on the surface roughness and color change of composite resins. J Prosthet Dent. Jul;96(1):33-40.

Wessel SW, Chen Y, Maitra A, van de Heuvel ER, Slomp AM, Busscher HJ, van der Mei HC. 2014 Adhesion forces and composition of planktonic and adhering oral microbiomes. J Dent Res 93:84-8.

Zhang YF, Zheng J, Zheng L, Zhou ZR.2015 Effect of adsorption time on the adhesion strength between salivary pellicle and human tooth enamel. J Mech Behav Biomed Mater 42:257-66. 